\title{
Maximum-Accumulation Snowpack Chemistry at Selected Sites in Northwestern Colorado During Spring 1994
}

by George P. Ingersoll

U.S. GEOLOGICAL SURVEY

Open-File Report 95-139

Prepared in cooperation with

ROUTT COUNTY, COLORADO 


\title{
U.S. DEPARTMENT OF THE INTERIOR \\ BRUCE BABBITT, Secretary
}

\author{
U.S. GEOLOGICAL SURVEY \\ Gordon P. Eaton, Director
}

The use of trade, product, industry, or firm names is for descriptive purposes only and does not imply endorsement by the U.S. Government.

For additional information write to:

District Chief

U.S. Geological Survey

Box 25046, MS 415

Denver Federal Center

Denver, CO 80225
Copies of this report can be purchased from:

U.S. Geological Survey

Earth Science Information Center

Open-File Reports Section

Box 25286, MS 517

Denver Federal Center

Denver, CO 80225 


\section{CONTENTS}

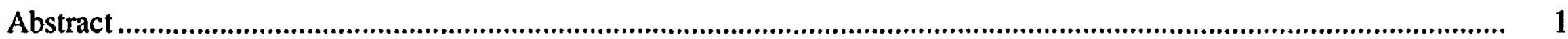

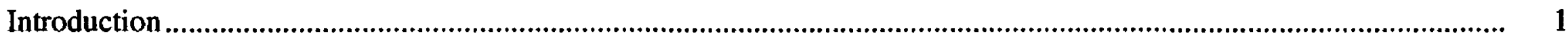

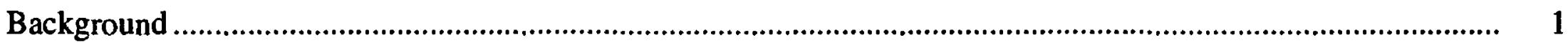

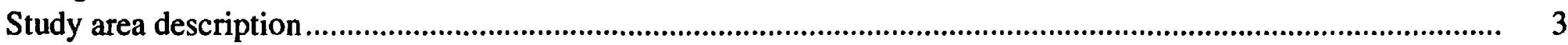

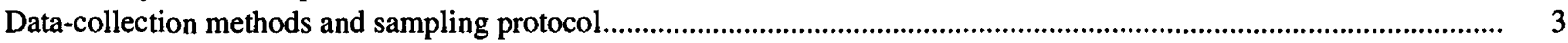

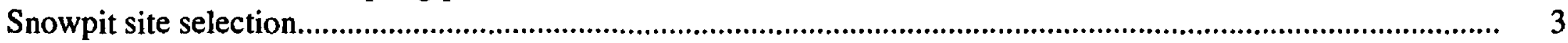

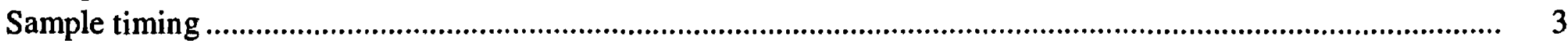

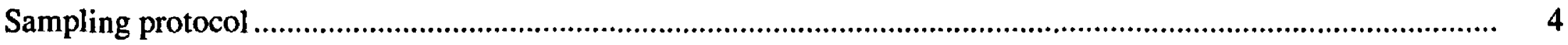

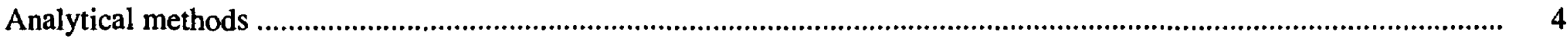

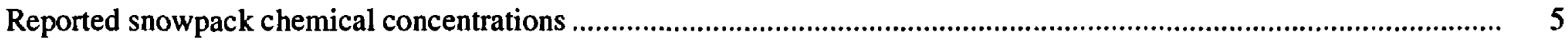

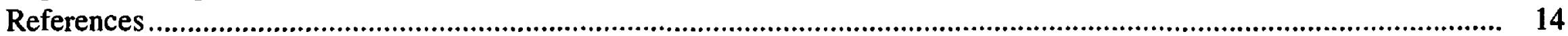

\section{FIGURES}

1-5. Maps showing:

1. General locations of selected snowpit sampling sites in northwestern Colorado................................... 2

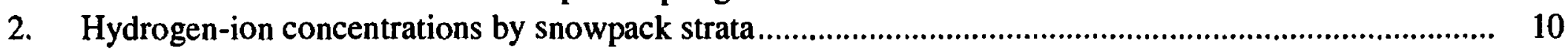

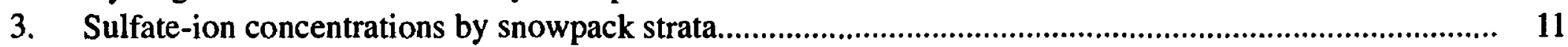

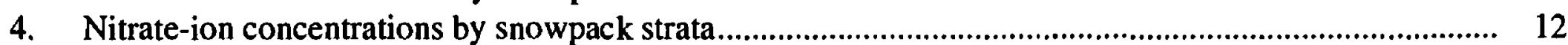

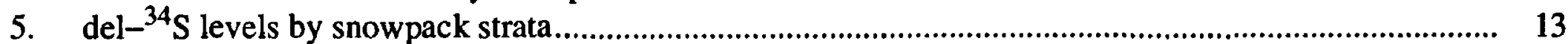

\section{TABLES}

1. Concentrations of dissolved organic carbon (DOC), $\mathrm{pH}$, and cations [hydrogen $\left(\mathrm{H}^{+}\right)$, ammonium $\left(\mathrm{NH}_{4}^{+}\right)$,

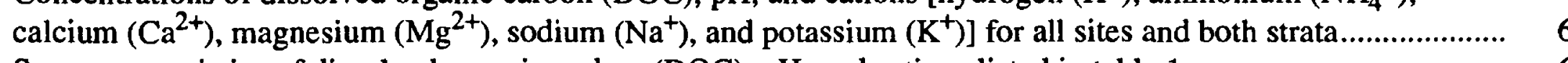

2. Summary statistics of dissolved organic carbon (DOC), $\mathrm{pH}$, and cations listed in table 1 .................................. 6

3. Concentrations of anions [chloride $\left(\mathrm{Cl}^{-}\right)$, sulfate $\left(\mathrm{SO}_{4}{ }^{2-}\right)$, and nitrate $\left(\mathrm{NO}_{3}^{-}\right)$], alkalinity, and del- ${ }^{34} \mathrm{~S}$, and percent charge balance for all sites and both strata

4. Summary statistics of anions, alkalinity, and del $-34 \mathrm{~S}$ listed in table 3

5. Concentrations of dissolved organic carbon (DOC), $\mathrm{pH}$, and cations [hydrogen $\left(\mathrm{H}^{+}\right)$, ammonium $\left(\mathrm{NH}_{4}{ }^{+}\right)$, calcium $\left(\mathrm{Ca}^{2+}\right)$, magnesium $\left(\mathrm{Mg}^{2+}\right)$, sodium $\left(\mathrm{Na}^{+}\right)$, and potassium $\left.\left(\mathrm{K}^{+}\right)\right]$at sampling site Rabbit Ears Pit 1 for upper and lower strata and substrata within each strata

6. Summary statistics of dissolved organic carbon (DOC), $\mathrm{pH}$, and cations listed in table 5 (10 10 12

7. Concentrations of anions [chloride $\left(\mathrm{Cl}^{-}\right)$, sulfate $\left(\mathrm{SO}_{4}{ }^{2-}\right)$, and nitrate $\left(\mathrm{NO}_{3}^{-}\right)$], alkalinity, and percent charge balance at sampling site Rabbit Ears Pit 1 for upper and lower strata and substrata within each strata..................

8. Summary statistics of anions and alkalinity listed in table 7 . 6 (1) 
CONVERSION FACTORS, VERTICAL DATUM, AND ABBREVIATIONS

\begin{tabular}{rll}
\hline Multiply & By & To obtain \\
\hline centimeter (cm) & 0.3937 & inch \\
kilometer & 0.6214 & mile \\
liter (L) & 0.2643 & gallon \\
meter & 3.281 & foot \\
\hline
\end{tabular}

Sea level: In this report "sea level" refers to the National Geodetic Vertical Datum of 1929 (NGVD of 1929)—a geodetic datum derived from a general adjustment of the first-order level nets of both the United States and Canada, formerly called Sea Level Datum of 1929.

Abbreviations used for water-quality terminology:

microequivalent per liter ( $\mu$ eq/L)

milligram per liter $(\mathrm{mg} / \mathrm{L})$ 


\title{
Maximum-Accumulation Snowpack Chemistry at Selected Sites in Northwestern Colorado During Spring 1994
}

\author{
By George P. Ingersoll
}

\begin{abstract}
Samples of the alpine and subalpine snowpack were collected in and near the headwater basins of the Yampa River in northwestern Colorado during maximum annual accumulation of snowpack in spring 1994. Sampling protocol at eight selected sites at more than 2,500 meters above sea level divided the snowpack into two distinct strata to enable separate chemical analyses of upper and lower layers of the annual snow cover. These two layers correspond to the beginning of the snow season in September until December 12, 1993, and the remainder of the season from January 1 until the sampling date in March or April 1994. At one site, these two strata were resampled at closely spaced intervals defining substrata to observe variance within the two strata dividing the snow season. Analytical results of snowpack chemistry are presented in support of investigations of seasonal effects on ion concentrations in the snowpack. Chemical concentrations of major anions and cations, dissolved organic carbon, and alkalinity; measured $\mathrm{pH}$; calculated charge balance between anions and cations; the stable-sulfur isotope ratio $\left({ }^{34} \mathrm{~S} /{ }^{32} \mathrm{~S}\right)$; and summary statistics of chemical concentrations are tabulated. Sampling sites are plotted on a map of the area. Spatial distributions of the concentrations of the hydrogen, nitrate, and sulfate ions and stable-sulfur isotope ratios also are mapped.
\end{abstract}

\section{INTRODUCTION}

The U.S. Geological Survey has established sites in northwestern Colorado for long-term monitoring of snow and lake chemistry. During spring 1994, the U.S. Geological Survey, in cooperation with Routt County, Colorado, collected data on concentrations of major chemical species in the snowpack at eight selected sites in northwestern Colorado (fig. 1). The data presented in this report include snowpit site selection, sample timing, sampling protocol, laboratory analytical methods, concentrations of major chemical constituents, relative amounts of the stable-sulfur isotope ratio, and summary statistics. The spatial distributions of these chemical concentrations in the annual snowpack are shown on maps.

\section{Background}

In conjunction with the selected sites discussed in this report, monitoring of the chemical concentrations in surface waters and snow at other sites in the alpine and subalpine areas of northwestern Colorado began in the mid-1980's (Turk and others, 1992). Synoptic snow sampling of the maximum-accumulation snowpack for water years 1991, 1992, and 1993 was performed at these and nearby sites (Turk and others, 1993). The snow-chemistry data presented here provide a reference for past, current, and future concentrations of chemical constituents in snow in alpine and subalpine regions of northwestern Colorado and support long-term monitoring studies of the water quality of the surface water in the study area.

In water years prior to 1993 in northwestern Colorado, snowpack chemistry was assessed using samples of the full snowpack column. The sampling method used at the selected sites presented in this report includes dividing the snowpack into two strata (upper and lower) to evaluate chemistry of the annual snowcover in the two layers separately. Details of the sample-collection procedures are presented in the "Data-Collection Methods and Sampling Protocol" section. 


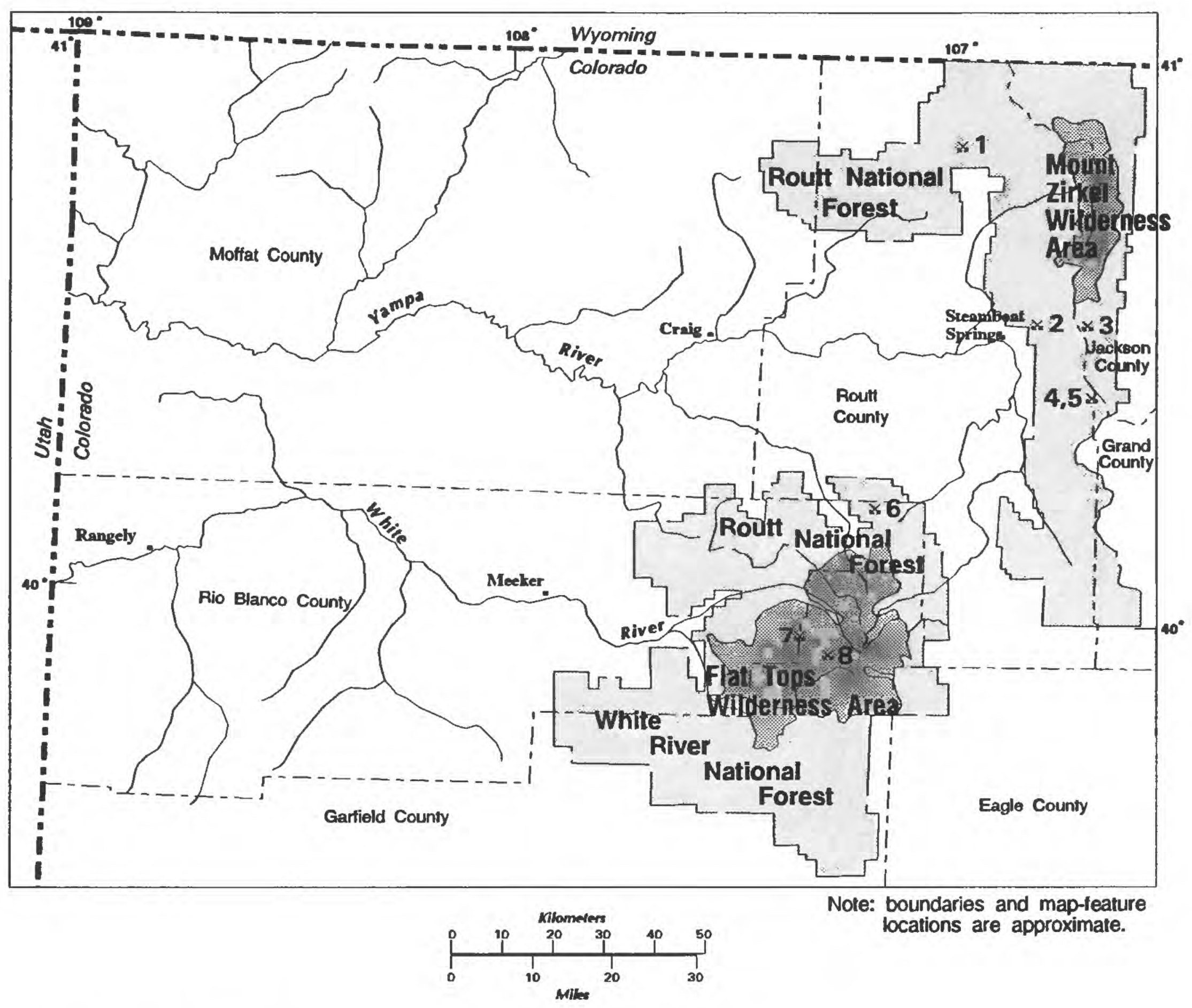

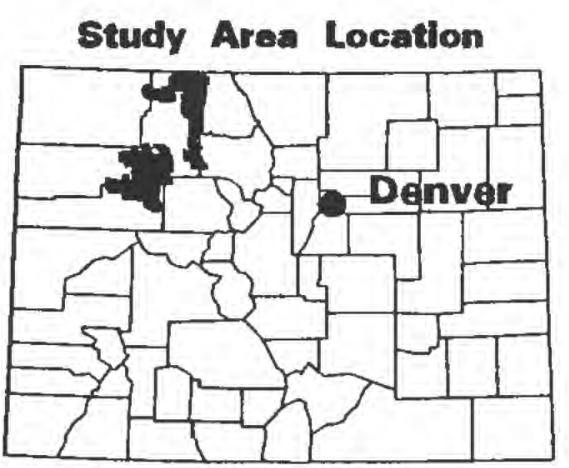

Colorado

\section{EXPLANATION}

Key to numbered
snowpit sltes: $\times 8$
1 Elk River
2 Dry Lake
3 Buffalo Pass
4 Rabbit Ears Pit 1
5 Rabbit Ears Pit 2
6 Dunckley Pass
7 Ned Wilson
8 Trappers Peak

Figure 1 General locations of selected snowpit sampling sites in northwestern Colorado. 
During maximum snowpack accumulation of spring 1993, sampling by upper and lower snow strata was first done in the area in and around the Mt. Zirkel Wilderness during a period of changing atmospheric emissions (John Turk, U.S. Geological Survey, written commun., 1993). The same strata were sampled again in 1994 during the same season to examine the seasonal changes in the snowpack chemistry and to assess changes in ionic concentrations in the annual snowpack during a period of more constant atmospheric emissions. At one of the eight sites sampled in 1994, Rabbit Ears Pit 1 (fig. 1), the two distinct strata were sampled in the same manner as at the other sites, but the upper and lower strata were resampled at closely spaced intervals to observe variance within the two main strata dividing the snow season. These substrata of the upper and lower strata were sampled to determine whether seasonal differences in chemistry between the upper and lower strata were more significant than differences between substrata within the upper or lower strata. Snow collected from the substrata represent fractions of the snow season and more nearly correspond to single storm events.

\section{Study Area Description}

The eight selected sampling sites are located near Steamboat Springs in northwestern Colorado near the headwaters of the Yampa River (fig. 1). Public lands in the Routt and White River National Forests surround the study area sampling sites. Bedrock, tundra grasses, aspen, and conifers dominate the landscape. The eight sites are at elevations of more than 2,500 meters above sea level where the seasonal snowpack is maintained throughout the winter and substantial melt does not occur until spring runoff. All sites are at least 50 meters from roadways to minimize contamination from vehicular traffic. Winter and spring temperatures typically drop below freezing nightly and preserve a cold snowpack until late March to early May, depending on elevation. Snowpack at the lowest site, Dry Lake, at 2,530 meters above sea level, begins to melt in the latter part of March or early April; the highest site, Trappers Peak, at 3,450 meters elevation, is snow covered well into May most years. Accessibility to sampling locations required various methods of transportation during the maximum-snowpack timeframe; helicopters and over-snow vehicles were necessary to reach the remote sampling sites. Distances from plowed roadways ranged from about 50 meters to 12 kilometers.

\section{DATA-COLLECTION METHODS AND SAMPLING PROTOCOL}

\section{Snowpit Site Selection}

Geographic locations of the sampling sites were chosen to cover an area of alpine and subalpine terrain surrounding the headwaters of the Yampa River (fig. 1). Snowpits were positioned in reasonably level clearings in forests where trees provided windbreaks and facilitated uniform snow accumulation. Snow cover free of onsite anthropogenic effects or other disturbances such as excessive tree litter or animal activity was chosen for sampling. Scoured or drifted areas were avoided because such areas would not best represent a cumulative seasonal snowpack that contained layers from all snowfall events. When possible, sites were collocated with Natural Resources Conservation Service snow-telemetry (SnoTel) instrument sites where measurements of snow-water equivalence (SWE) were reported daily. These SWE levels from SnoTel sites were in turn used to define the boundary between the separate snow strata sampled.

\section{Sample Timing}

The timing of maximum seasonal snowpack accumulation for water year 1994 (WY94) snowfall events was estimated from 30-year-averaged, maximum-SWE values reported from SnoTel sites near the sampling sites.

Where SnoTel instrumentation was not collocated with a sampling site, the nearest SnoTel site at a similar elevation was used to estimate daily amounts of SWE. Biweekly SWE values for the 30-year period 1961-90 were used to forecast timeframes when snowmelt might begin. Sampling dates were fixed at 2 or 3 weeks before the forecasted maximum SWE timeframe to collect samples before episodes of earlier than usual melting and consequently reduce the chance of loss of chemical solutes held in the snowpack throughout the winter and spring. Actual sampling dates were from 12 to 29 days before the reported dates of maximum accumulations at the reference SnoTel sites. 


\section{Sampling Protocol}

The total depth of the seasonal snowpack for WY94 was divided into an upper and lower component corresponding to the accumulated annual snowcover for these two periods of time: the beginning of the season in September until December 12, 1993, and the remainder of the season from January 1 until the sampling date in March or April 1994. A buffer zone of the snowpack between the upper and lower layers of snow corresponding to the time interval December 12,1993, to January 1,1994, was not sampled in order to reduce the possibility of overlap of the upper and lower layers. Thicknesses of these buffer zones not sampled at the eight sampling sites ranged from 10 to 50 centimeters; total snow depths ranged from 110 to 260 centimeters.

Approximating the location of this buffer zone defining the boundary between strata was done by locating sample snowpits near SnoTel sites, if possible, and using cumulative SWE values as measured daily at the SnoTel sites for the time interval bounding the buffer zone. Reported SWE values from the SnoTel sites for three dates were used to approximate the buffer zone delimiting the upper and lower strata: (1) The date used as the final day of accumulation of the lower strata, December 12,1993; (2) the date marking the beginning of the top strata, January 1, 1994; and (3) a date close to the actual sampling date. Density measurements were made in each of the snowpits at the eight sites where snow samples were collected, and SWE was computed at 10- or 20-centimeter intervals vertically throughout the snowpack. The percentage of SWE reported at a nearby SnoTel site was calculated for the dates December 12, 1993, and January 1, 1994, relative to a recent day before the sampling date.

These percentages of accumulated SWE at the SnoTel sites prior to the dates December 12, 1993, and January 1,1994, were applied to the total SWE measured in the sample snowpits to estimate the amount of SWE at the boundaries of the buffer zone between the upper and lower strata. For example, the Buffalo Pass snowpit was prepared on April 8,1994, and a record of the measured SWE at the nearest SnoTel site was available for the entire season up to the previous day. The SWE reported from the SnoTel site for April 7, 1994 (representing cumulative SWE to date for WY94), was used to calculate the percentage of SWE on December 12, 1993, and January 1, 1994. Reported values of SWE for those 3 days were $100,38.4$, and 50.3 centimeters, respectively. Dividing the SWE for each date defining the buffer zone timeframe by the cumulative SWE on the last reported day before sampling gives: $38.4 / 100=0.38$ or 38 percent, corresponding to December 12,1993 , and $50.3 / 100=0.50$ or 50 percent, corresponding to January 1, 1994. So, by December $12,1993,38$ percent of the SWE reported for the whole snow season as of April 7, 1994, was present at the SnoTel site. And by January 1, 1994, 50 percent of the SWE for the period was reported. Measured SWE values were summed at 10or 20-centimeter intervals vertically from the bottom to the top of the snowpack in the sample snowpits. SWE values at the positions on that cumulative-SWE vertical profile corresponding to the percentage (as in the example above) of cumulative SWE reported at SnoTel sites identified the depths used to divide the two snow layers. Accordingly, 38 percent of the measured SWE in the Buffalo Pass pit was taken as the upper limit of the lower stratum, and 50 percent of the measured SWE was taken as the lower limit of the upper stratum.

Snowpits were prepared with a smooth, freshly cut, vertical face extending from the ground surface upward throughout the entire depth of the snowpack. Separate samples were collected for each of the upper and lower layers. The bottom 10 centimeters of the snowpack was not sampled to avoid inclusion of forest litter and soils in the samples. Accordingly, the top 5 centimeters of snowpack were discarded to prevent contamination from activities resulting from transport to and preparation of the snowpit. Latex laboratory gloves were worn, and clean plastic shovels and scoops were used to collect a vertical column for each sample representative of the entire stratum to be analyzed. The columns were cut and placed in prerinsed 8-liter Teflon bags and 60-liter plastic carboys. These containers were sealed against contamination and transported to the U.S. Geological Survey Regional Research Laboratory in Boulder, Colorado, for analysis.

\section{ANALYTICAL METHODS}

Snow samples from all eight sites were allowed to melt and were processed using a variety of analytical procedures. Major cation concentrations were determined using two emission-spectroscopy techniques-inductively coupled plasma [for species: calcium $\left(\mathrm{Ca}^{2+}\right)$, magnesium $\left(\mathrm{Mg}^{2+}\right)$, and sodium $\left(\mathrm{Na}^{+}\right)$] and atomic absorption [for potassium $\left(\mathrm{K}^{+}\right)$only]. Detection limits for the emission-spectroscopy instruments were $0.35,0.58,0.43$, and $1.3 \mu \mathrm{eq} / \mathrm{L}$ for $\mathrm{Ca}^{2+}, \mathrm{Mg}^{2+}, \mathrm{Na}^{+}$, and $\mathrm{K}^{+}$, respectively. Chloride $\left(\mathrm{Cl}^{-}\right)$, nitrate $\left(\mathrm{NO}_{3}^{-}\right)$, and sulfate $\left(\mathrm{SO}_{4}{ }^{2-}\right)$ anion levels were obtained by ion chromatography; detection limits were $0.56,0.14$, and $0.42 \mu \mathrm{eq} / \mathrm{L}$, respectively. 
Ammonium $\left(\mathrm{NH}_{4}^{+}\right)$ion concentrations were calculated by air-segmented, continuous-flow colorimetry with a detection limit of $0.43 \mu \mathrm{eq} / \mathrm{L}$. Analysis of the stable-sulfur isotope ratio $\left({ }^{34} \mathrm{~S} /{ }^{32} \mathrm{~S}\right)$ used mass spectrometry to determine the del- ${ }^{34} \mathrm{~S}$ values in parts per mil $(\%)$ relative to the del $-{ }^{34} \mathrm{~S}$ value for the standard reference Canyon Diablo Troilite (Faure, 1986). Specific conductance and $\mathrm{pH}$ were computed with appropriate laboratory meters. Alkalinity measurements were taken from Gran titration calculations. Dissolved organic carbon (DOC) levels were obtained using infrared detection.

Quality control was performed by systematically analyzing deionized-water (DI) blanks, reference samples, locally prepared reference standards, and U.S. Geological Survey reference standards. Approximately 40 percent of sample batch run time for the analytical instrumentation was dedicated to processing blanks, reference samples, and standards. Calibration verifications were made with standards at the beginning and end of each batch of sample analyses. Blanks were created and analyzed to detect contamination sources from DI, filter elements used to filter samples, and the Teflon bags used to collect snow samples. As an internal reference sample to monitor instrument precision, water from Chaos Creek in Rocky Mountain National Park, Colorado, was selected for its similarity of ionic strength compared to snowmelt from the sites reported here. A duplicate snowpit (Rabbit Ears Pit 2) was sampled at Rabbit Ears Pass. All concentration levels determined by atomic spectroscopy were analyzed twice and mean values calculated. Charge balance was calculated between anions and cations at all sites.

\section{REPORTED SNOWPACK CHEMICAL CONCENTRATIONS}

Snowpack chemical concentrations are presented in tables $1,3,5$, and 7 , and a table summarizing basic statistics of the chemical concentrations (means, standard deviations, minimum value, and maximum value) follows each data table (tables 2, 4, 6, and 8). Relative values for concentrations of $\mathrm{H}^{+}, \mathrm{SO}_{4}{ }^{2-}, \mathrm{NO}_{3}^{-}$, and del- ${ }^{34} \mathrm{~S}$ in upper and lower strata are shown geographically for each sample location in figures 2-5. 
Table 1. Concentrations of dissolved organic carbon (DOC), $\mathrm{pH}$, and cations [hydrogen $\left(\mathrm{H}^{+}\right)$, ammonium $\left(\mathrm{NH}_{4}^{+}\right)$, calcium $\left(\mathrm{Ca}^{2+}\right)$, magnesium $\left(\mathrm{Mg}^{2+}\right)$, sodium $\left(\mathrm{Na}^{+}\right)$, and potassium $\left.\left(\mathrm{K}^{+}\right)\right]$for all sites and both strata

[(u), upper strata; (l), lower strata; DOC in milligrams per liter; cations in microequivalents per liter]

\begin{tabular}{|c|c|c|c|c|c|c|c|c|c|}
\hline $\begin{array}{l}\text { Sampling } \\
\text { site name }\end{array}$ & $\begin{array}{c}\text { Sampling } \\
\text { date }\end{array}$ & DOC & pH & $\mathrm{H}^{+}$ & $\mathrm{NH}_{4}{ }^{+}$ & $\mathrm{Ca}^{2+}$ & $\mathrm{Mg}^{2+}$ & $\mathrm{Na}^{+}$ & $\mathbf{K}^{+}$ \\
\hline Buffalo Pass (u) & $04-08-94$ & 0.78 & 4.72 & 19.1 & 14.6 & 13.8 & 3.0 & 2.7 & $\overline{0.4}$ \\
\hline Buffalo Pass (l) & $04-08-94$ & 0.49 & 4.82 & 15.1 & 4.3 & 2.6 & 0.9 & 0.6 & 0.2 \\
\hline Dry Lake (u) & 03-19-94 & 0.48 & 4.74 & 18.2 & 6.4 & 9.6 & 2.1 & 3.1 & 0.1 \\
\hline Dunckley Pass (u) & $03-24-94$ & 0.51 & 5.17 & 6.8 & 4.3 & 14.1 & 3.1 & 2.1 & 0.3 \\
\hline Dunckley Pass (1) & $03-24-94$ & 0.43 & 5.16 & 6.9 & 4.6 & 11.6 & 2.0 & 1.4 & 1.6 \\
\hline Elk River (u) & 03-19-94 & 0.52 & 4.99 & 10.2 & 5.0 & 10.1 & 2.0 & 1.8 & 0.4 \\
\hline Elk River (1) & $03-19-94$ & 1.19 & 5.25 & 5.6 & 8.2 & 9.5 & 1.7 & 0.9 & 1.3 \\
\hline Rabbit Ears Pit 1 (u) & $03-23-94$ & 0.54 & 4.93 & 11.7 & 5.7 & 10.8 & 2.3 & 2.8 & 0.2 \\
\hline Rabbit Ears Pit 1 (l) & $03-23-94$ & 0.42 & 4.75 & 17.8 & 4.6 & 5.5 & 1.4 & 2.3 & 0.0 \\
\hline Rabbit Ears Pit 2 (u) & $03-23-94$ & 0.47 & 4.92 & 12.0 & 6.8 & 13.4 & 2.7 & 5.1 & 0.1 \\
\hline Rabbit Ears Pit 2 (l) & $03-23-94$ & 0.47 & 4.94 & 11.5 & 5.7 & 6.0 & 1.4 & 2.5 & 0.0 \\
\hline Trappers Peak (u) & $03-31-94$ & 0.37 & 5.39 & 4.1 & 3.2 & 9.5 & 1.6 & 1.6 & 0.1 \\
\hline Trappers Peak (1) & $03-31-94$ & 0.41 & 5.01 & 9.8 & 3.6 & 4.8 & 1.0 & 1.7 & 0.3 \\
\hline
\end{tabular}

Table 2. Summary statistics of dissolved organic carbon (DOC), $\mathrm{pH}$, and cations listed in table 1

[DOC in milligrams per liter; for $\mathrm{pH}$ statistics, the median is listed in place of the mean; cations in microequivalents per liter]

\begin{tabular}{|l|c|c|c|c|c|c|c|c|}
\hline & DOC & pH & $\mathbf{H}^{+}$ & $\mathrm{NH}_{4}^{+}$ & $\mathrm{Ca}^{2+}$ & $\mathrm{Mg}^{2+}$ & $\mathrm{Na}^{+}$ & $\mathrm{K}^{+}$ \\
\hline \hline Mean & 0.56 & 4.965 & 11.1 & 5.55 & 8.88 & 1.87 & 2.02 & 0.41 \\
\hline Standard deviation & 0.2 & Not calculated & 5.35 & 2.80 & 3.56 & 0.66 & 1.13 & 0.45 \\
\hline Number of samples & 16 & 16 & 16 & 16 & 16 & 16 & 16 & 16 \\
\hline Maximum & 1.19 & 5.50 & 19.1 & 14.6 & 14.1 & 3.1 & 5.1 & 1.6 \\
\hline Minimum & 0.37 & 4.72 & 3.2 & 2.5 & 2.6 & 0.9 & 0.6 & 0.0 \\
\hline
\end{tabular}


Table 3. Concentrations of anions [chloride $\left(\mathrm{Cr}^{-}\right)$, sulfate $\left(\mathrm{SO}_{4}{ }^{2-}\right)$, and nitrate $\left(\mathrm{NO}_{3}{ }^{-}\right)$], alkalinity, and del- ${ }^{34} \mathrm{~S}$, and percent charge balance for all sites and both strata

[(u), upper strata; (l), lower strata; anions and alkalinity in microequivalents per liter; del- ${ }^{34} \mathrm{~S}$ in parts per mil]

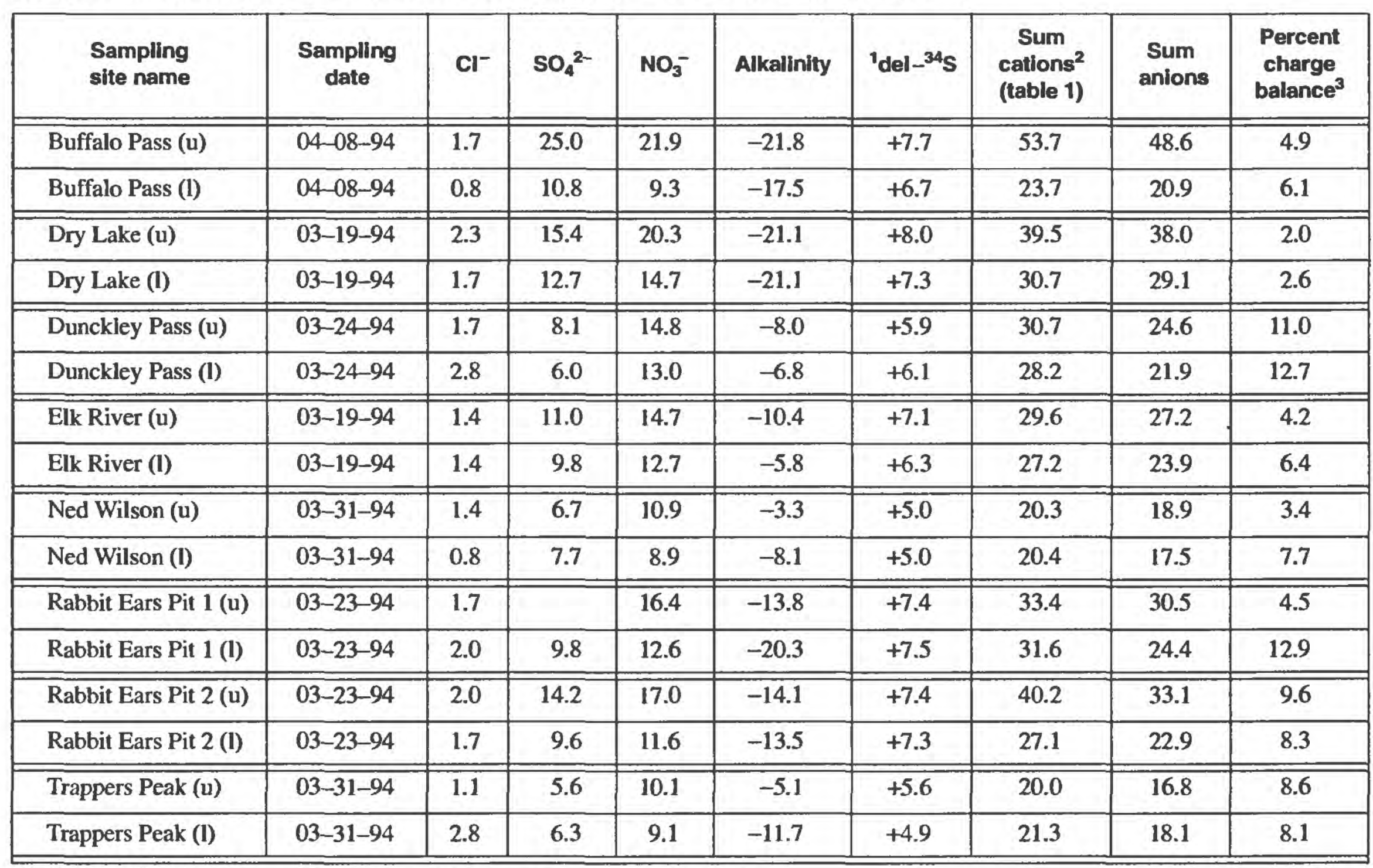

${ }^{1} \mathrm{del}^{-{ }^{34} \mathrm{~S}}$ values expressed as parts per mil relative to Canyon Diablo Troilite.

${ }^{2}$ Sum of cations and sum of anions based on unrounded values.

${ }^{3}$ Charge balance for all anions and cations is calculated as: $100 \times$ (sum of cations - sum of anions) / (sum of cations + sum of anions).

Table 4. Summary statistics of anions, alkalinity, and del- ${ }^{34} \mathrm{~S}$ listed in table 3

[Anions and alkalinity, in microequivalents per liter; del- ${ }^{34} \mathrm{~S}$ in parts per mil]

\begin{tabular}{|l|c|c|c|c|c|}
\hline & $\mathrm{Cl}^{-}$ & $\mathrm{so}_{4}^{2-}$ & $\mathrm{NO}_{3}^{-}$ & Alkalinity & ${ }^{{ }^{-}}{ }^{-1 e l-{ }^{34} S}$ \\
\hline \hline Mean & 1.71 & 10.7 & 13.6 & -12.7 & 6.6 \\
\hline Standard deviation & 0.59 & 4.82 & 3.86 & 6.25 & 1.04 \\
\hline Number of samples & 16 & 16 & 16 & 16 & 16 \\
\hline Maximum & 2.8 & 25.0 & 21.9 & -3.3 & 8.0 \\
\hline Minimum & 0.8 & 5.6 & 8.9 & -21.8 & 4.9 \\
\hline
\end{tabular}

${ }^{1}$ del- ${ }^{34} \mathrm{~S}$ values expressed as parts per mil relative to Canyon Diablo Troilite. 
Table 5. Concentrations of dissolved organic carbon (DOC), $\mathrm{pH}$, and cations [hydrogen $\left(\mathrm{H}^{+}\right)$, ammonium $\left(\mathrm{NH}_{4}{ }^{+}\right)$, calcium $\left(\mathrm{Ca}^{2+}\right)$, magnesium $\left(\mathrm{Mg}^{2+}\right)$, sodium $\left(\mathrm{Na}^{+}\right)$, and potassium $\left(\mathrm{K}^{+}\right)$] at sampling site Rabbit Ears Pit 1 for upper and lower strata and substrata within each strata

[cm, centimeters; DOC in milligrams per liter; cations in microequivalents per liter]

\begin{tabular}{|c|c|c|c|c|c|c|c|c|c|}
\hline $\begin{array}{c}\text { Sampled snow strata } \\
\text { and range of snow depth at } \\
\text { Rabbit Ears Pit 1 (cm) }\end{array}$ & $\begin{array}{c}\text { Sampling } \\
\text { date }\end{array}$ & $\mathbf{D O C}$ & $\mathbf{p H}$ & $\mathbf{H}^{+}$ & $\mathbf{N H}_{4}{ }^{+}$ & $\mathbf{C a}^{2+}$ & $\mathbf{M g}^{2+}$ & $\mathrm{Na}^{+}$ & $\mathbf{K}^{+}$ \\
\hline \hline Upper stratum, 150-234 & $03-23-94$ & 0.54 & 4.93 & 11.7 & 5.7 & 10.8 & 2.3 & 2.8 & 0.2 \\
\hline Upper substratum, 222-234 & $03-23-94$ & 0.65 & 6.37 & 0.4 & 10.4 & 30.3 & 4.6 & 4.5 & 0.4 \\
\hline Upper substratum, 210-222 & $03-23-94$ & 0.52 & 5.31 & 4.9 & 12.5 & 23.2 & 4.2 & 6.7 & 0.4 \\
\hline Upper substratum, 198-210 & $03-23-94$ & 0.49 & 5.17 & 6.8 & 11.1 & 19.7 & 3.9 & 5.0 & 0.4 \\
\hline Upper substratum, 186-198 & $03-23-94$ & 0.80 & 4.77 & 17.0 & 8.6 & 16.3 & 3.2 & 6.6 & 0.5 \\
\hline Upper substratum, 174-186 & $03-23-94$ & 0.40 & 4.82 & 15.1 & 3.6 & 4.4 & 1.0 & 1.8 & 0.0 \\
\hline Upper substratum, 162-174 & $03-23-94$ & 0.39 & 4.82 & 15.1 & 3.6 & 3.0 & 0.9 & 1.0 & 0.0 \\
\hline Upper substratum, 150-162 & $03-23-94$ & 0.55 & 4.61 & 24.5 & 5.4 & 8.8 & 2.2 & 2.2 & 0.3 \\
\hline Lower stratum, 0-100 & $03-23-94$ & 0.42 & 4.75 & 17.8 & 4.6 & 5.5 & 1.4 & 2.3 & 0.0 \\
\hline Lower substratum, 75-100 & $03-23-94$ & 0.59 & 4.96 & 11.0 & 6.4 & 6.5 & 1.7 & 1.7 & 0.2 \\
\hline Lower substratum, 50-75 & $03-23-94$ & 0.69 & 4.71 & 19.5 & 4.6 & 5.3 & 1.5 & 1.2 & 0.0 \\
\hline Lower substratum, 25-50 & $03-23-94$ & 0.39 & 4.88 & 13.2 & 3.6 & 2.6 & 0.7 & 0.4 & 0.2 \\
\hline Lower substratum, 0-25 & $03-23-94$ & 0.57 & 5.00 & 10.0 & 4.3 & 6.2 & 1.6 & 2.5 & 0.6 \\
\hline
\end{tabular}

Table 6. Summary statistics of dissolved organic carbon (DOC), $\mathrm{pH}$, and cations listed in table 5

[DOC in milligrams per liter, for $\mathrm{pH}$ statistics, the median is listed in place of the mean; cations in microequivalents per liter]

\begin{tabular}{|l|c|c|c|c|c|c|c|c|}
\hline & $\mathrm{DOC}$ & $\mathrm{pH}$ & $\mathrm{H}^{+}$ & $\mathrm{NH}_{4}^{+}$ & $\mathrm{Ca}^{2+}$ & $\mathrm{Mg}^{2+}$ & $\mathrm{Na}^{+}$ & $\mathrm{K}^{+}$ \\
\hline Mean & 0.55 & 4.88 & 12.5 & 6.7 & 11.5 & 2.3 & 3.1 & 0.27 \\
\hline Standard deviation & 0.13 & Not calculated & 6.87 & 3.33 & 9.39 & 1.41 & 2.26 & 0.21 \\
\hline Number of samples & 11 & 11 & 11 & 11 & 11 & 11 & 11 & 11 \\
\hline Maximum & 0.80 & 6.37 & 24.5 & 12.5 & 30.3 & 4.6 & 6.7 & 0.6 \\
\hline Minimum & 0.39 & 4.61 & 0.4 & 3.6 & 2.6 & 0.7 & 0.4 & 0.0 \\
\hline
\end{tabular}

${ }^{1}$ Eleven substrata are summarized in these statistics; upper $(150-234 \mathrm{~cm})$ and lower strata $(0-100 \mathrm{~cm})$ were not included in the calculations for this table. 
Table 7. Concentrations of anions [chloride $\left(\mathrm{Cl}^{-}\right)$, sulfate $\left(\mathrm{SO}_{4}{ }^{2-}\right)$, and nitrate $\left(\mathrm{NO}_{3}^{-}\right)$], alkalinity, and percent charge balance at sampling site Rabbit Ears Pit 1 for upper and lower strata and substrata within each strata

[cm, centimeters; anions and alkalinity in microequivalents per liter]

\begin{tabular}{|c|c|c|c|c|c|c|c|c|}
\hline $\begin{array}{l}\text { Sampled snow strata } \\
\text { and range of snow depth at } \\
\text { Rabblt Ears Plt } 1(\mathrm{~cm})\end{array}$ & $\begin{array}{l}\text { Sampling } \\
\text { date }\end{array}$ & $\mathrm{Cl}^{-}$ & $\mathrm{SO}_{4}{ }^{2-}$ & $\mathrm{NO}_{3}^{-}$ & Alkalinity & $\begin{array}{l}\text { Sum } \\
\text { cations } \\
\text { (table 5) }\end{array}$ & $\begin{array}{l}\text { Sum } \\
\text { anlons }\end{array}$ & $\begin{array}{l}\text { Percent } \\
\text { charge } \\
\text { balance }{ }^{2}\end{array}$ \\
\hline Uppet stratum; $150-234$ & $03-23-94$ & 1.7 & 12.5 & 16.4 & $-13,8$ & 33.4 & 30.5 & 4.5 \\
\hline Upper substratum, 222-234 & $03-23-94$ & 2.3 & 17.3 & 12.9 & 13.3 & 50.6 & 45.8 & 5.0 \\
\hline Upper substratum, 210-222 & $03-23-94$ & 4.5 & 19.6 & 18.4 & -4.2 & 51.9 & 42.4 & 10.0 \\
\hline Upper substratum, 198-210 & $03-23-94$ & 4.5 & 17.7 & 20.1 & -8.1 & 46.8 & 42.3 & 5.1 \\
\hline Upper substratum, 186-198 & $03-23-94$ & 3.1 & 20.8 & 21.9 & -18.7 & 52.1 & 45.8 & 6.4 \\
\hline Upper substratum, 174-186 & $03-23-94$ & 2.0 & 11.0 & 12.4 & -17.4 & 25.8 & 25.4 & 0.8 \\
\hline Upper substratum, 162-174 & $03-23-94$ & 1.7 & 8.8 & 12.4 & -16.6 & 23.5 & 22.8 & 1.5 \\
\hline Upper substratum, 150-162 & $03-23-94$ & 2.8 & 11.3 & 23.4 & -26.8 & 43.4 & 37.5 & 7.3 \\
\hline Lower stratum, $0-100$ & $03-23-94$ & 20 & 9.8 & 12.6 & -20.3 & 31.6 & 24,4 & 129 \\
\hline Lower substratum, 75-100 & $03-23-94$ & 1.7 & 10.2 & 11.9 & -12.3 & 27.5 & 23.8 & 7.2 \\
\hline Lower substratum, $50-75$ & $03-23-94$ & 2.0 & 9.6 & 14.8 & -21.6 & 32.1 & 26.3 & 9.9 \\
\hline Lower substratum, 25-50 & $03-23-94$ & 1.4 & 9.2 & 8.2 & -14.9 & 20.7 & 18.8 & 4.8 \\
\hline Lower substratum, 0-25 & $03-23-94$ & 0.8 & 10.2 & 11.5 & -11.4 & 25.2 & 22.6 & 5.4 \\
\hline
\end{tabular}

${ }^{1}$ Sum of cations and sum of anions based on unrounded values.

${ }^{2}$ Charge balance for all anions and cations is calculated as: $100 \times$ (sum of cations - sum of anions) / (sum of cations + sum of anions).

Table 8. Summary statistics of anions and alkalinity listed in table 7

[Anions and alkalinity in microequivalents per liter]

\begin{tabular}{|l|c|c|c|c|}
\hline & $\mathrm{Cl}^{-}$ & $\mathrm{SO}_{4}{ }^{2-}$ & $\mathrm{NO}_{3}^{-}$ & Alkalinity \\
\hline \hline Mean & 2.4 & 13.3 & 15.3 & -12.6 \\
\hline Standard deviation & 1.20 & 4.59 & 4.91 & 10.6 \\
\hline Number of samples & 11 & 11 & 11 & 11 \\
\hline Maximum & 4.5 & 20.8 & 23.4 & 13.3 \\
\hline Minimum & 0.8 & 8.8 & 8.2 & -26.8 \\
\hline
\end{tabular}

${ }^{1}$ Eleven substrata are summarized in these statistics; upper (150-234 cm) and lower strata $(0-100 \mathrm{~cm})$ were not included in the calculations for this table. 


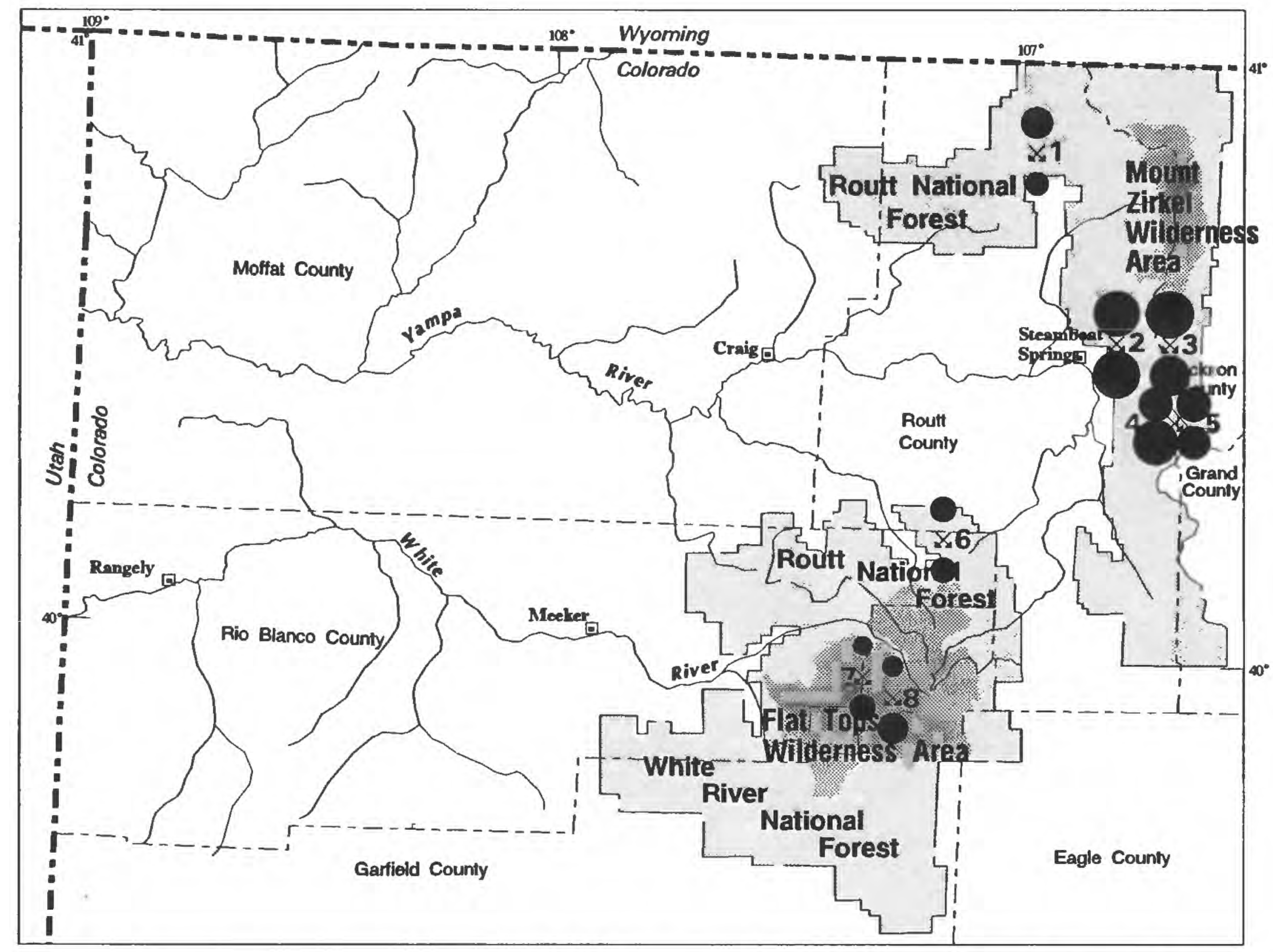

Note: Spot diameters representing hydrogen-ion concentrations are linearly related to levels reported (twice the diameter represents twice the level). Map-feature locations are approximate.

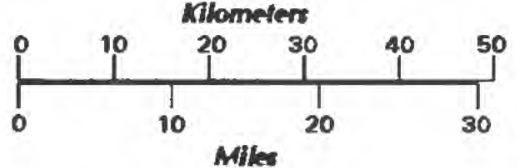

\section{EXPLANATION}

Key to numbered snowplt sites: upper-strata concentration

1 Elk River

2 Dry Lake $\bigcirc$ lower-strata concentration

3 Buffalo Pass

4 Rabbit Ears Pit 1

5 Rabbit Ears Pit 2

6 Dunckley Pass

7 Ned Wilson

8 Trappers Peak

Figure 2 Hydrogen-ion concentrations by snowpack strata. 


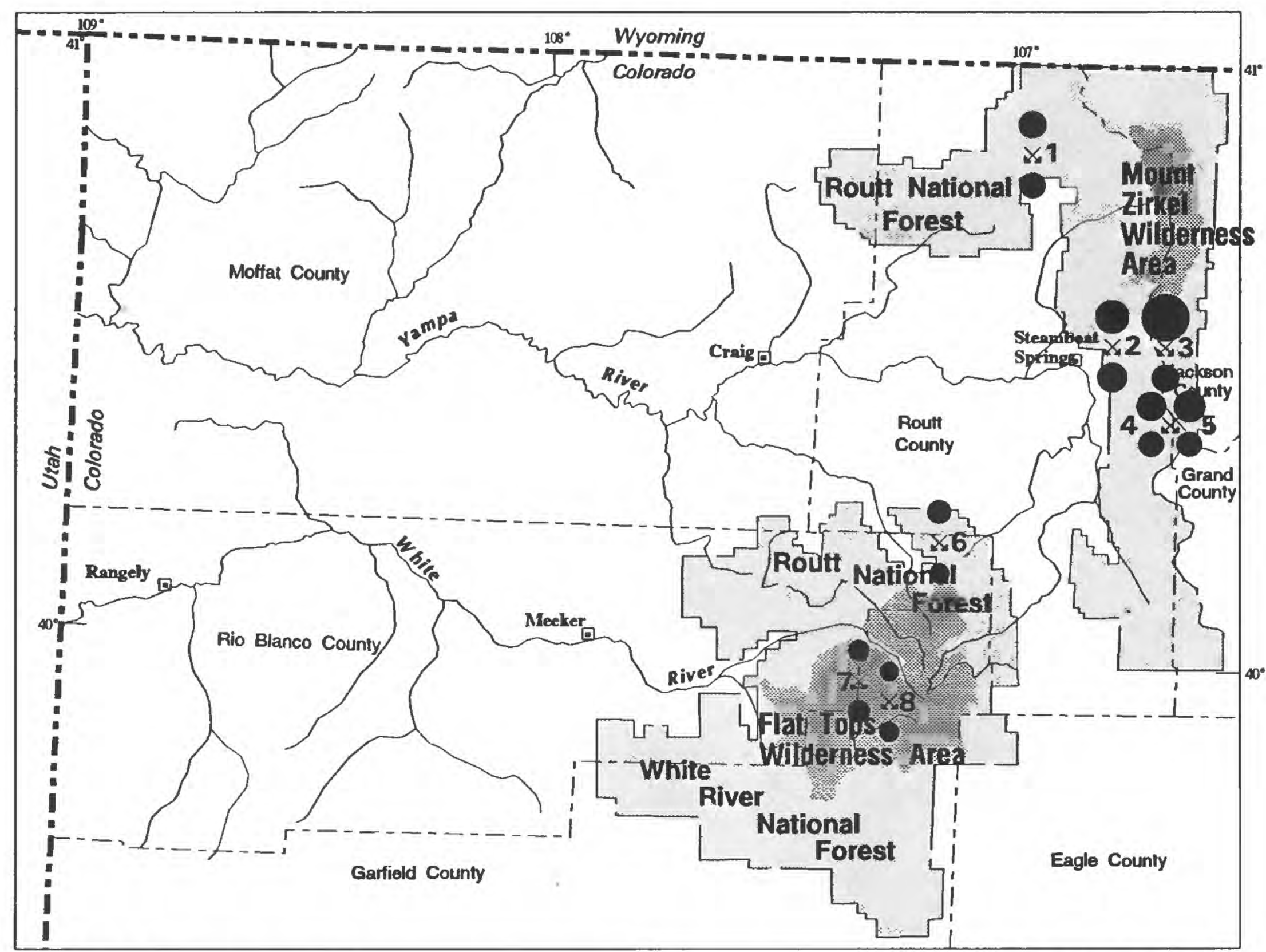

Note: Spot diameters representing sulfate-ion concentrations are linearly related to levels reported (twice the diameter represents twice the level). Map-feature locations are approximate.

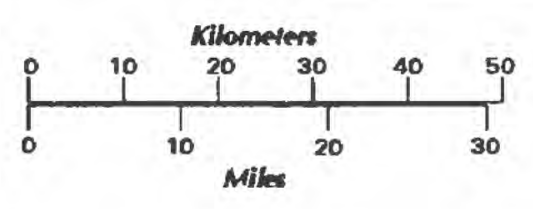

Range $=5.6$ to 25.0 microequivalents per liter for all selected sites.

\section{EXPLANATION}

Key to numbered snowplt sltes:

$\begin{array}{ll}\text { snowplt sltes: } & \text { upper-strata concentration } \\ 1 & \text { Elk River } \times 8 \text { lower-strata concentration } \\ 2 & \text { Dry Lake } \\ 3 & \text { Buffalo Pass } \\ 4 & \text { Rabbit Ears Pit } 1 \\ 5 & \text { Rabbit Ears Pit } 2 \\ 6 & \text { Dunckley Pass } \\ 7 & \text { Ned Wilson } \\ 8 & \text { Trappers Peak }\end{array}$

Figure 3 Sulfate-ion concentrations by snowpack strata. 


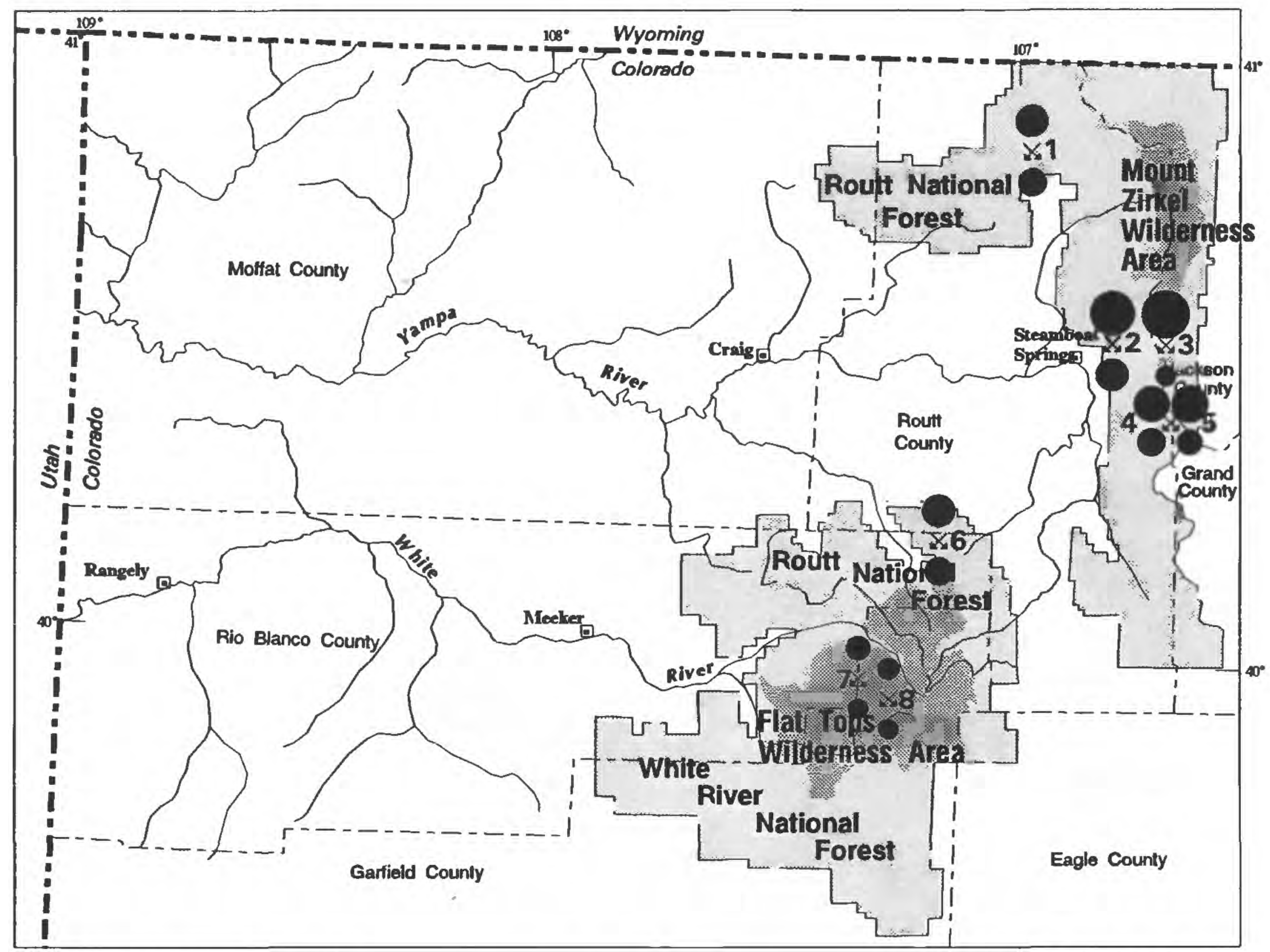

Note: Spot diameters representing nitrate-ion concentrations are linearly related to levels reported (twice the diameter represents twice the level). Map-feature locations are approximate.

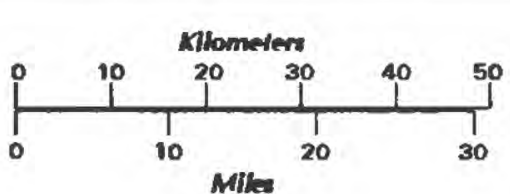

Range $=8.9$ to 21.9 microequivalents per liter for all selected sites.

\section{EXPLANATION}

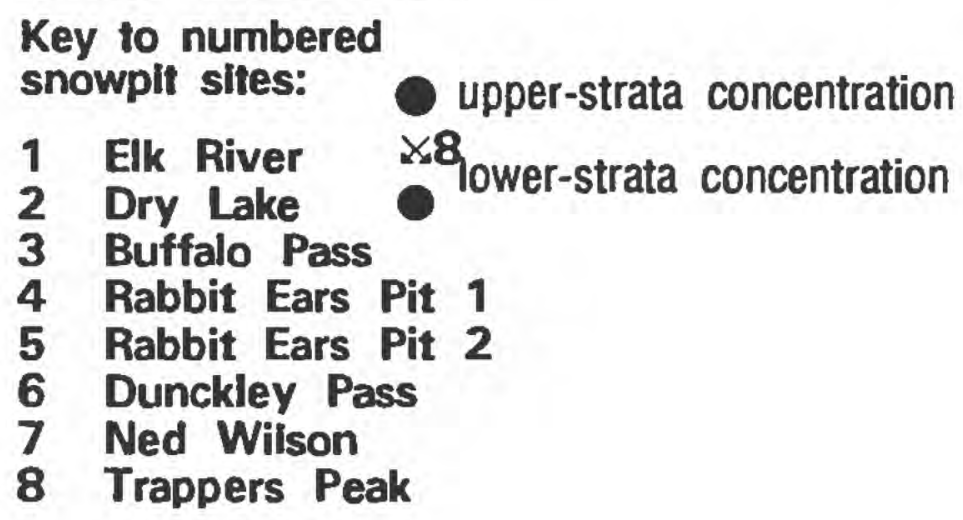

Figure 4 Nitrate-ion concentrations by snowpack strata. 


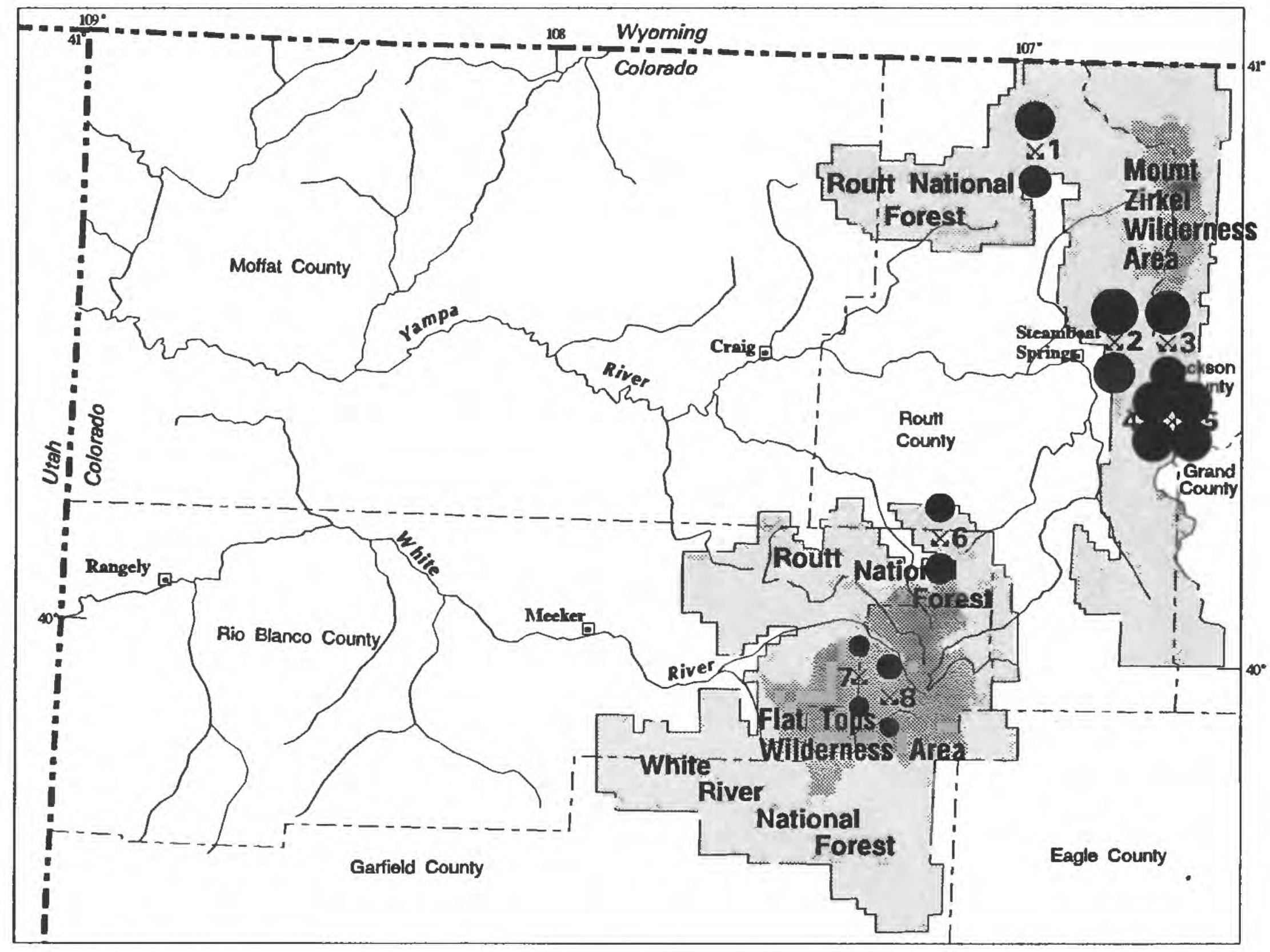

Note: Spot diameters representing del- ${ }^{34} \mathrm{~S}$ concentrations are linearly related to levels reported (twice the diameter represents twice the level). Map-feature locations are approximate.

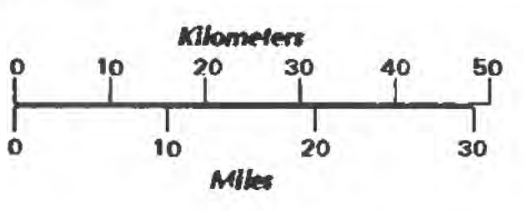

Range $=4.9$ to 8.0 (parts per mil) for all selected sites.

\section{EXPLANATION}

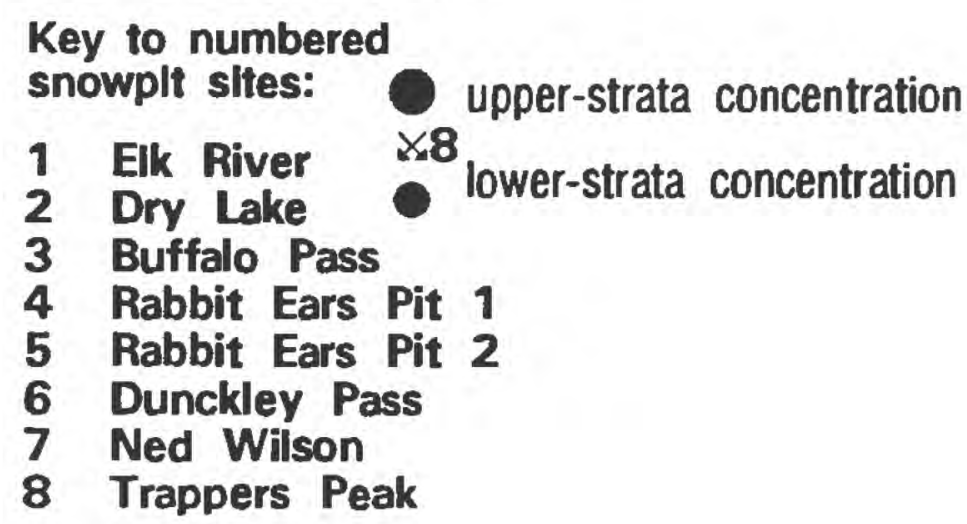

Figure 5 del ${ }^{34} S$ levels by snowpack strata. 


\section{REFERENCES}

Faure, G., 1986, Principles of Isotope Geology (2d ed.): New York, N.Y., John Wiley and Sons, 589 p.

Turk, J.T., Campbell, D.H., Ingersoll, G.P., and Clow, D.W., 1992, Initial findings of synoptic snowpack sampling in the Colorado Rocky Mountains: U.S. Geological Survey Open-File Report 92-645, 6 p.

Turk, J.T., Campbell, D.H., and Spahr, N.E., 1993, Use of chemistry and stable sulfur isotopes to determine sources of trends in sulfate of Colorado lakes: Water, Air, and Soil Pollution, v. 67, p. 415-431. 